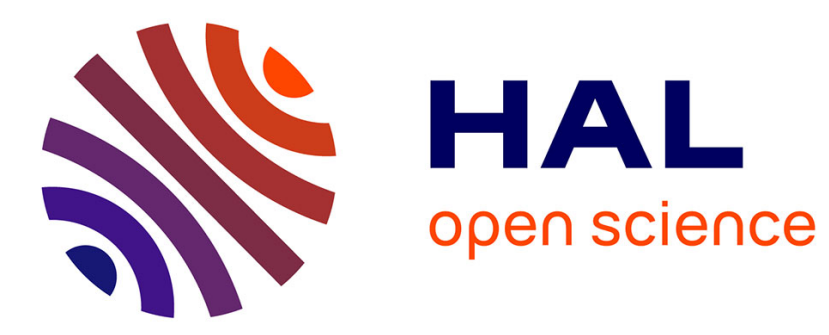

\title{
Trade, foreign direct investment and economic growth in Asian economies
}

\author{
Xiaohui Liu, Chang Shu, Peter Sinclair
}

\section{To cite this version:}

Xiaohui Liu, Chang Shu, Peter Sinclair. Trade, foreign direct investment and economic growth in Asian economies. Applied Economics, 2009, 41 (13), pp.1603-1612. 10.1080/00036840701579176 . hal-00581980

\section{HAL Id: hal-00581980 \\ https://hal.science/hal-00581980}

Submitted on 1 Apr 2011

HAL is a multi-disciplinary open access archive for the deposit and dissemination of scientific research documents, whether they are published or not. The documents may come from teaching and research institutions in France or abroad, or from public or private research centers.
L'archive ouverte pluridisciplinaire HAL, est destinée au dépôt et à la diffusion de documents scientifiques de niveau recherche, publiés ou non, émanant des établissements d'enseignement et de recherche français ou étrangers, des laboratoires publics ou privés. 


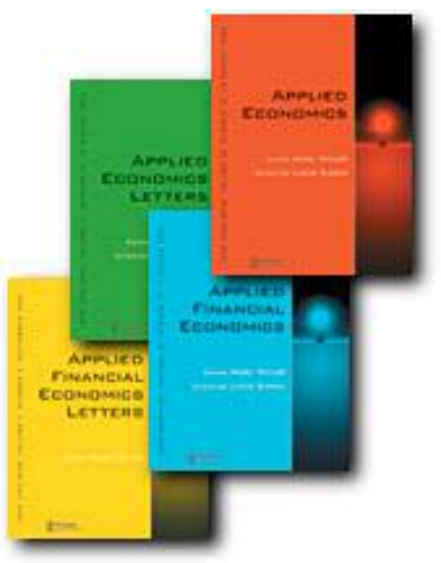

Trade, foreign direct investment and economic growth in Asian economies

\begin{tabular}{|c|l|}
\hline Journal: & Applied Economics \\
\hline Manuscript ID: & APE-05-0478.R1 \\
\hline Journal Selection: & Applied Economics \\
\hline JEL Code: & $\begin{array}{l}\text { C32 - Time-Series Models < C3 - Econometric Methods: } \\
\text { Multiple/Simultaneous Equation Models < C - Mathematical and } \\
\text { Quantitative Methods, O53 - Asia including Middle East < O5 - } \\
\text { Economywide Country Studies < O - Economic Development, } \\
\text { Technological Change, and Growth, F21 - International } \\
\text { Investment|Long-Term Capital Movements < F2 - International } \\
\text { Factor Movements and International Business < F - International } \\
\text { Economics }\end{array}$ \\
\hline \hline Keywords: & \begin{tabular}{l} 
Trade, Foreign direct investment, Asian Economies , the VECM \\
\hline
\end{tabular} \\
\hline
\end{tabular}

\section{S) ScholaroNE \\ Manuscript Central}




\title{
Trade, foreign direct investment and economic growth in Asian economies
}

\author{
Xiaohui Liu* \\ Business School \\ Loughborough University \\ Chang Shu \\ Hong Kong Monetary Authority \\ Peter Sinclair \\ Department of Economics \\ University of Birmingham
}

August 2005

Running title: Trade, FDI and Economic Growth

\begin{abstract}
Despite the increasing role of foreign direct investment (FDI) in economic development, very limited research has been carried out on the causal links between trade, FDI and economic growth in Asian economies. This study examines empirically the interplay between exports, imports, FDI and economic growth for nine Asian economies by conducting multivariate causality tests in the VECM framework. The results reveal twoway causal connections between the four variables for most of the sample economies. These findings suggest that export expansion, import liberalisation and FDI inflows are integral parts of the growth process in Asian economies.
\end{abstract}

\footnotetext{
* Corresponding author: Business School, Loughborough University, Leicestershire, LE11 3TU; Tel No 01509-223349; Fax No: 01509-223171; Email: X.liu2@lboro.ac.uk
} 


\title{
Trade, foreign direct investment and economic growth in Asian economies
}

\author{
1 Introduction
}

Empirical investigation of the causal link between trade and economic growth is an important theme in trade and development literature. A large number of empirical studies have been carried out on causality between trade and growth, particularly for East Asian economies (Hsiao, 1987; Chen and Tang, 1990; Ahmad and Harnhirun, 1995; Islam, 1998; Kwan et al, 1999; Hatemi-J, 2002 and Jin, 2002; Love and Chandra, 2004; Thangavelu and Rajaguru, 2004). These studies have shed some light on the issue and provided some useful insights regarding the evaluation of trade and development strategies. However, most of the existing studies exclude foreign direct investment (FDI) and only consider trade-growth linkage, despite the fact that FDI inflows and multinationals have become the driving forces of economic growth and technology transfer (Kokko, 1994; Oulton, 1998; Xu, 2000). Over the last two decades, East Asian economies, in particular, have received increasing amounts of inward FDI which reached a record level of US\$143 billion in 2000 (UNCTAD, 2001). In contrast, comparatively few studies have been conducted on the relationship between trade, FDI and economic growth for Asian economies in a multivariate framework.

It is important to examine the linkage between trade, FDI and economic growth for Asian economies in order to provide evidence as to whether rapid economic growth in the region is driven by trade and FDI, or whether there is reciprocal impact between growth, trade and FDI. Such an investigation is able to explore to what degree the 
positive association between trade, FDI and growth is due to the fact that trade and FDI stimulate growth, and to what extent this positive association reflects the fact that growth leads to trade and FDI. Moreover, by including economies at different stages of development in the study, it is possible to address the question of whether the level of development affects the pattern of the relationship between the four important economic variables. From a policy point of view, investigating the causal links between trade, FDI and growth generates important implications for the development strategies of developing countries.

The sample used in this study consists of the first and second wave of newly industrialised economies (NIEs) in East Asia, notably Hong Kong, Singapore, South Korea, Taiwan, Indonesia, Malaysia, the Philippines and Thailand. In addition, a large developing country in the region, India, is also included. An appropriate model will be selected for individual economies in order to best capture the complicated relationship between these variables.

This research differs from previous studies in several ways. First, instead of using different measures of openness and trade policy, we examine the three basic elements of development strategy, notably exports, imports and FDI. Most of the previous causality tests assume implicitly that the coefficients on exports and imports are homogeneous (Krishna, et al, 2003) and use trade shares as a measure of openness. However, in this study, we treat exports and imports separately to allow for the possibility that their influence is asymmetric. Second, we regard FDI as a key factor of economic growth, given that in addition to its direct contribution to GDP, FDI has played an increasingly important role in technology transfer and R\&D spillovers in 
developing countries (Blomstrom and Sjoholm, 1999; Gao, 2004). Therefore, we consider exports, imports and FDI as external links, and attempt to test the causal relationship between these factors and economic development in selected Asian economies.

The paper is structured as follows: Section 2 discusses the theoretical foundations for possible bi-directional linkage between external factors and economic growth. Section 3 introduces the methodology and data used in the study, while the following section presents and analyses empirical results. Section 5 concludes with policy implications.

2 Trade, FDI and Growth: a discussion of theoretical linkage and the empirical evidence

The theoretical foundations for empirical studies on trade, FDI and growth are derived from neo-classical and endogenous growth models. In neo-classical growth models, factor accumulation is considered as a driving force of growth. FDI, as a factor of production, increases investment as well as enhances efficiency, and provides growth momentum in the medium-term. Application of the Solow model (1956) implies that a trade-induced rise in production leads to transitional growth when the economy adjusts to a new steady- state equilibrium as specialisation and the realisation of external economies of scale through trade allow the economy to transform its given input into a greater value of final output. Ben-David and Loewy (2003) extend the traditional neoclassical exogenous growth model by incorporating the impact of openness on growth within a multi-country framework and the results from their model indicate that 
the extent of trade liberalisation can affect the endogenously determined growth rate in the steady state.

The new endogenous growth models establish the links between long-run growth and technological progress, and provide a framework in which trade and FDI can permanently increase the rate of growth in the host country through technology transfer, diffusion, and spillover effects. Romer (1993) points out that one benefit that trade brings is access to new ideas. Grossman and Helpman (1991) have constructed a theoretical model to show formally that trade in goods serves as a conduit for knowledge flows between countries. These flows in turn serve to increase the productivity of capital and labour and hence the growth rate of per capita output. Borensztein et al (1998) develop a growth model in which technological progress, represented by increasing varieties of capital goods, is determined by FDI as multinationals can reduce the costs of introducing new varieties of capital goods. Thus, FDI acts as the main vehicle of technology transfer. In addition, the human capital building model as presented by Lucas (1988) may suggest that trade and FDI could enable inter-country technology transfer.

Although trade and FDI are important for economic growth, the causal link between them is not necessarily uni-directional as the level of economic development can also influence trade and FDI. Theoretical justifications for reverse causation from growth to trade and FDI have long been discussed in development literature (Kanamori, 1968; Diaz-Alejandro, 1975; Kravis, 1970; Findlay, 1984). It is argued that output growth has a positive impact on productivity growth, which in turn acts as a stimulus to exports (Kaldor, 1967). Jung and Marshall (1985) suggest that internal growth 
mechanisms better explain export growth rather than the reverse. In new trade theory, the market structure and output expansion may trigger significant changes in exports through a process of "cumulative causation" (Venables, 1996). A more recent study by Berthelemy and Demurger (2000) has theoretically established that FDI is influenced by the growth rate of the economy in the long run, and thus provides a formal justification of the causal link between growth and FDI.

Given the possible bi-directional relationship between trade, FDI and economic growth postulated by the theories, the issue becomes empirical and can be verified through statistical tests. Attempts have been made to establish a causal link between trade, FDI and growth empirically. Previous studies in this area fall roughly into three groups. The first group focuses on the impact of trade or openness on economic growth. Early works, including Balassa (1978, 1984), Feder, (1983), and Kavoussi (1984), only consider causation running from exports to economic growth. Studies of this kind assume implicitly that exports are exogenous without taking into account reverse causation.

Studies in the second group examine the impact of economic growth on FDI. The extent to which FDI can be explained by economic growth is the focus of attention, particularly the determinants of FDI in developing countries (Wang, and Swain, 1997; Dees, 1998). These studies, which assume one-way causality from growth to FDI, appear to indicate that the growth potential in developing economies is the main determinant of inward FDI. These studies have, however, also neglected the possible simultaneity between FDI and growth. 
The third group of studies attempts to investigate bi-directional causal links between trade and growth or FDI and growth, by conducting causality tests. Mixed results have been obtained. Jung and Marshall (1985) have found that only four out of 37 developing countries support the export-led growth hypothesis. Studies by Chow (1987), Hsiao (1987), and Chen and Tang (1990) are only able to provide weak support for the export-led growth hypothesis even for highly export-oriented economies such as Hong Kong, Singapore and Taiwan. Those results are consistent with Young's findings (1994) which indicate that outward orientation may or may not be associated with rapid productivity growth, and the fast expansion of East Asian NIEs should not be viewed as evidence of the potential dynamic gains from outward-oriented policies. On the other hand, Ahmad and Harnhirun (1995), Biswal and Dhawan (1998), Islam (1998), Shan and Sun (1998) have found bi-directional causality for most of the East Asian NIEs and China. However, most of the cited studies have treated exports as the principal channel through which openness can affect economic growth. None of them include FDI inflows in their empirical analysis despite the fact that East Asian economies have received increasing amounts of inward FDI. Therefore, using trade as a proxy for openness may be inadequate without taking the impact of FDI into account (Goldberg and Klein, 1999). Furthermore, the existence of a FDI-growth nexus is not considered by excluding FDI variable from causality tests.

The recent study by Nair-Reichert and Weinhold (2001) acknowledges the problems mentioned above by considering the complex and heterogeneous relationship between FDI and growth. They have found a causal relationship from FDI to growth, and some evidence that the efficacy of FDI is higher in more open economies. However, 
in their study, imports are not used as the measure of openness and this may underestimate the impact of trade induced by imports (Keller and Yeaple, 2003). Extending previous work in this area, the present study attempts to estimate the complex interaction between trade, FDI and growth for selected Asian economies in a multivariate framework.

3 The methodology and data

We are interested in the interplay of four variables, GDP, FDI, Exports and Imports; to set the scene, therefore, consider a VAR involving four variables, W, X, Y, and Z. In a stationary setting, a Granger causality test in such a structure would be carried out (following Ghartey, 1993) via the following regressions:

$$
\begin{aligned}
& W_{t}=\delta_{0}+\sum_{i=1}^{m} \delta_{1 i} W_{t-i}+\sum_{j=1}^{m} \delta_{2 j} Z_{t-j}+\sum_{k=1}^{m} \delta_{3 k} Y_{t-k}+\sum_{l=1}^{m} \delta_{4 l} X_{t-l}+u_{1 t} \\
& X_{t}=\varphi_{0}+\sum_{i=1}^{n} \varphi_{1 i} X_{t-i}+\sum_{j=1}^{n} \varphi_{2 j} Y_{t-j}+\sum_{k=1}^{n} \varphi_{3 k} Z_{t-k}+\sum_{l=1}^{n} \varphi_{4 l} W_{t-l}+u_{2 t}
\end{aligned}
$$

$$
Y_{t}=\theta_{0}+\sum_{i=1}^{p} \theta_{1 i} Y_{t-i}+\sum_{j=1}^{p} \theta_{2 j} X_{t-j}+\sum_{k=1}^{p} \theta_{3 k} Z_{t-k}+\sum_{l=1}^{p} \theta_{4 l} w_{t-l}+u_{3 t}
$$

$$
Z_{t}=\gamma_{0}+\sum_{i=1}^{q} \gamma_{1 i} Z_{t-i}+\sum_{j=1}^{q} \gamma_{2 j} Y_{t-j}+\sum_{k=1}^{q} \gamma_{3 k} X_{t-k}+\sum_{l=1}^{q} \gamma_{4 l} W_{t-l}+u_{4 t}
$$

$t=1,2, \ldots, N$ 
where the lag lengths, $(m, n, p, q)$ are determined so that $u_{1 t}, u_{2 t}, u_{3 t}$ and $u_{4 t}$ are serially uncorrelated. The null hypothesis ' $Y$ does not Granger cause $X$, given $W$ and $Z$ ' is tested via a standard F- test, being rejected if the $\varphi_{2 j}$ in equation (2) are jointly significant. Similarly, if the $\theta_{2 j}$ in equation (3) are jointly significantly different from zero, the null hypothesis that $X$ does not Granger cause $Y$, given $W$ and $Z$, is rejected and so on. However, if the series are non-stationary, it becomes important to determine whether or not they are cointegrated, as this affects the sampling distributions of the causality tests. Toda and Phillips (1993) show that levels autoregressions are an unreliable basis for inference about causality in the nonstationary case, since the sampling distributions of the test statistics depend on the ranks of certain sub-matrices in the cointegrating space. They thus favour the use of the VECM framework of Johansen (1988) in which the necessary information about the cointegrating space is available, and where causality test statistics will usually have asymptotic Chi-square distributions. We adopt this approach.

When the series in the VAR are cointegrated, and have two cointegrating vectors, ignoring the higher-order dynamics, equations (1)-(4) above can be rewritten in the VECM form:

$\left[\begin{array}{c}\Delta W \\ \Delta X \\ \Delta Y \\ \Delta Z\end{array}\right]_{t}=\left[\begin{array}{ll}\alpha_{11} & \alpha_{12} \\ \alpha_{21} & \alpha_{22} \\ \alpha_{31} & \alpha_{32} \\ \alpha_{41} & \alpha_{42}\end{array}\right]\left[\begin{array}{llll}\beta_{11} & \beta_{12} & \beta_{13} & \beta_{14} \\ \beta_{21} & \beta_{22} & \beta_{23} & \beta_{24}\end{array}\right]\left[\begin{array}{c}W \\ X \\ Y \\ Z\end{array}\right]_{t-1}+\left[\begin{array}{l}\varepsilon_{1} \\ \varepsilon_{2} \\ \varepsilon_{3} \\ \varepsilon_{4}\end{array}\right]_{t}$

where the parameters of interest are in the long-run (i.e. cointegrating) vectors, $\beta_{i j}$, and 
the adjustment coefficients (loading factors), $\alpha_{i j}$. Hall and Milne (1994, P.600-601) introduce the notion of the absence of weak causality to denote the situation in which the long-run level of one or more variables is unaffected by the levels of others. In equation (5), this is testable via zero restrictions on $\alpha_{i j}$. Following Hall and Milne, if weak non-causality is rejected, then Granger non-causality, which in addition involves the remaining higher-order short-run dynamics, is also rejected. Thus bi-directional causality can be explored by estimating the full VECM proposed in equation (5), and testing restrictions on the long-run adjustment coefficients.

Data

Annual data for the value of exports and imports in goods for nine economies are taken from UNCTAD (2003). The export and import price indices are used to deflate the value of exports and imports for most economies, but GDP deflators $(1995=100)$ are used as an alternative when such an index is not available in the cases of Singapore and Thailand. There are several sources for obtaining inward FDI including the UNCTAD (2003), Reserve Bank of India (2003) and Bank Indonesia (2003). Annual GDP series are taken from the International Financial Statistics (2003). Both GDP series and inward FDI are deflated using GDP deflators. The sample period spans from 1970 to 2002 for the nine economies.

4 Empirical results

Unit root tests 
The series are transformed into logarithms so that the first differences correspond to growth rates. Table 1 presents the results from ADF unit root tests with lag length chosen by downward search (t-test on the longest lag). The null hypothesis of a unit root in the logarithm is not rejected for any of the four variables in levels. However, each of the logged series is stationary in first differences. Therefore all the variables are integrated of order one.

Insert Table 1 here

\section{Cointegration tests}

When testing cointegration relationships we first need to decide whether deterministic components such as constant, time trend and dummy variables should be included in the model. Using the general-to-specific approach, a specific model for each economy is chosen. The selection criterion for lag length is the combination of Akaike Information Criterion and diagnostic tests. The selected lag length should enable residuals to pass various diagnostic tests, including serial correlation, normality test, function form, $\mathrm{ARCH}$ and heteroskedasticity.

Second, the test for cointegration rank described by Johansen and Juselius (1990) is applied, and the results are reported in Table 2. Both trace statistics and maximal eigenvalue statistics show that the VAR for each economy has two cointegrating vectors; both are significant at the $5 \%$ and $1 \%$ levels. The existence of cointegration between the variables suggests that there are long-run relationships between the four variables, implying that there is a tendency for the four variables to move together. 
Insert Table 2 here

\section{Testing for weak exogeneity and causality}

The results from cointegration tests indicate that the causality tests should be conducted via Equation (5). As stated in the methodology section, the main interest of the study is to test long-run relationships, hence we investigate the long-run causality between the four variables which is equivalent to testing long-run loading factors in equation (5), such as $a_{i j}=0$. The results reported in Table 3 reveal that exports, imports and FDI affect GDP in most of the sample economies at the $1 \%$ or $5 \%$ significance levels. The results confirm that external links represented by exports, imports and FDI have generated beneficial effects on economic growth in most of the sample economies, indicating that the external links may act as the principal channel through which technology spillover and learning-by-doing take place as suggested by endogenous growth theories. The evidence that economies with different levels of development exhibit the same pattern in trade-growth and FDI-growth nexus suggests that trade and FDI are important factors in enhancing economic growth, regardless of the initial level of development.

Insert Table 3 here

It should be noted that the null hypothesis, that GDP is exogenous, is rejected only at the $10 \%$ significance level in the cases of India and South Korea. This may 
reflect the fact that India has been a relatively closed economy with an inward-looking policy which was relaxed relatively late, with final removal of its last features coming only in the mid-1990s. Therefore, it is highly likely that the impact of trade and FDI on GDP is relatively small at the aggregate level. However, it is very surprising that Korean GDP is only weakly affected by external factors, given that the remarkably rapid economic growth over most of the last few decades has been accompanied by persistent export expansion. The possible reason may be that South Korea has adopted an export promotion policy under import protection. It is also well known that the Korean government restricted inward FDI until the Asian financial crisis. All these factors may create distortion, and limit the impact of trade and FDI on GDP.

The null hypothesis that FDI is exogenous is universally rejected across the sample economies, implying that inward FDI is attracted by the growth prospects and the level of external trade in the region. The results are consistent with previous studies which have found that rapid GDP growth and intensive external trade act as the main determinants of inward FDI (Broadman and Sun, 1997; Sun, 1998).

The evidence rejects the null hypothesis that exports are exogenous for all the sample economies. The only weak result obtained is for Malaysia where the null hypothesis is rejected at the $10 \%$ significance level, showing a weak causal link between exports and the other three variables. The results indicate that exports and the other three variables mutually affect each other. In terms of imports, the results in seven out of nine sample economies reject the hypothesis that imports are exogenous, suggesting that imports are linked to GDP, exports and FDI. However, the null hypothesis is not rejected in the cases of India and Malaysia, confirming that only a one-way causal link 
running from imports to GDP exists. Import-led growth has been achieved in these two countries. In particular, Indian imports grew faster than exports between 1970 and 1990. Import liberalisation helped reduce import shortages, and hence facilitated economic growth (Nidugala, 2000).

Based on the four weak exogeneity tests (weak causality - after Hall and Milne) which massively reject the null hypothesis for each of the four variables for seven out of nine sample economies, we conclude that each is weakly caused by the other three. This implies in turn that we have bi-directional Granger causality for the majority of the sample economies. Bi-directional causalities between the four variables do not support a trade-led or a FDI-led growth hypothesis (Kwan and Kwok, 1995; Nair-Reichert and Weinhold, 2001). The findings suggest that export expansion, import liberalisation and FDI inflows are integral elements in the economic growth process and that these external links go hand in hand with growth in Asian economies.

\section{Conclusions}

This study examines empirically the causal links between FDI, trade and growth for nine Asian economies by conducting multivariate causality tests in the VECM framework. The results reveal two-way causal connections between trade, FDI and growth for most of the sample economies, indicating that external links and growth mutually affect each other. The findings suggest that export expansion, import liberalisation and FDI inflows are integral elements in the growth process in the sample Asian economies. The existence of bi-directional causal links suggests that development strategies should be 
designed to promote inward FDI, trade and growth simultaneously.

References

\begin{abstract}
Ahmad, J. and Harnhirun, S. (1995) Unit roots and cointegration in estimating causality between exports and economic growth: empirical evidence from the ASEAN countries, Economics Letters, 49, 329-334.
\end{abstract}

Balassa, B. (1978) Exports and economic growth: further evidence, Journal of Development Economics, 5, 181-189.

(1985) Exports and policy choices and economic growth in developing countries after the 1973 oil crisis, Journal of Development Economics, 18, 23-35.

Bank Indonesia (2003) Annual report for direct investment and services and investment income in 2002.

Berthelemy, J. and Demurger, S. (2000) Foreign direct investment and economic growth: theory and application to China, Review of Development Economics, 4, 140155.

Biswal, B. and Dhawan, U. (1998) Export-led growth hypothesis: cointegration and causality analysis for Taiwan, Applied Economics Letters, 5, 699-701.

Ben-David, D. and Loewy, M. (2003) Trade and the Neoclassical growth model, Journal of Economic Integration, 18, 1-16.

Blomstrom, M. and Sjoholm, F. (1999) Technology transfer and spillovers: Does local participation with multinationals matter?, European Economic Review, 43, 915-923.

Borensztein, E., Gregorio, J. and Lee, J. (1998) How does foreign direct investment 
affect economic growth', Journal of International Economics, 45, 115-135.

Broadman, G and Sun, X. (1997) The distribution of foreign direct investment in China, World Economy, 20, 339-361.

Chen, S., and Tang, D. (1990) Exports performance and productivity growth: the case of Taiwan, Economic Development and Cultural Change, 38, 577-585.

Chow, P. (1978) Causality between exports and industrial development: empirical evidence from the NICs, Journal of Development Economics, 26, 55-63.

Dees, S. (1998) Foreign direct investment in China: determinants and effects, Economics of Planning, 31, 175-194.

Diaz-Alejandro, C. (1975) Trade policy and economic development in P Kenen (ed.) International Trade and Finance: Frontiers for Research, New York, Cambridge University Press.

Feder, G. (1983) On exports and economic growth', Journal of Development Economics, 12, 59-73.

Findlay, R. (1984) Growth and development in trade model in R. Jones and Kenen (eds), Handbook of International Economics (I), Amsterdam, North-Holland.

Gao, T. (2004) Regional industrial growth: evidence from Chinese industries', Regional Science and Urban Economics, 34, 101-124

Ghartey, E. (1993) Causal relationship between exports and economic growth: some empirical evidence in Taiwan, Japan and the US, Applied Economics, 25, 1145-1152.

Goldberg, S., and Klein, W. (1999) International trade and factor mobility: an empirical investigation, NBER Working Paper No. 1796.

Grossman, G. and Helpman, E. (1991) Innovation and growth in the global economy, 
MIT Press, Cambridge, MA.

Hall, S. and Milne, A. (1994) The relevance of p-star analysis to UK monetary policy, Economic Journal, 104, 597-604.

Hatemi-J, A. (2002) Export performance and economic growth nexus in Japan: a bootstrap approach, Japan and World Economy, 14, 25-33.

Hsiao, M. (1987) Tests of causality and exogeneity between exports and economic growth: the case of Asian NICs, Journal of Economic Development, 12, 143-159.

International Financial Statistics Yearbook (2003). Annual GDP series, IMF.

Islam, M. (1998) Export expansion and economic growth: testing for cointegration and causality, Applied Economics, 30, 415-425.

Jin, J. (2002) Exports and growth: is the export-led growth hypothesis valid for provincial economies? Applied Economics, 34, 63-76.

Johansen, S. (1988) Statistical analysis of cointegration vectors, Journal of Economic Dynamics and Control, 12, 213-254.

Johansen. S. and Juselius, K. (1990) Maximum likelihood estimation and inference on cointegration-with applications to the demand for money, Oxford Bulletin of Economics and Statistics, 52, 169-210.

Jung, W. and Marshall, P. (1985) Exports, growth and causality in developing countries, Journal of Development Economics, 18, 1-12.

Kaldor, N. (1967) Strategic Factors in Economic Development, New York State School of Industrial and Labour Relations, Cornell University, Ithaca, NY.

Kanamori, M. (1968) Economic growth and exports in R. Klein and K. Ohkawa (eds), Economic Growth, Richard D. Irwn. 
Kavoussi, R. (1984) Export expansion and economic growth: further empirical evidence', Journal of Development Economics, 14, 241-250.

Keller, W. and Yeaple, S. (2003) Multinational enterprises, international trade, and productivity growth: firm level evidence from the United States', NBER Working Paper, No. 9504.

Kokoo, A. (1994) Technology market characteristics and spillovers', Journal of Development Economics, 43, 279-293.

Kravis, I. (1970) Trade as a handmaiden of growth: similarities between the $19^{\text {th }}$ and $20^{\text {th }}$ Centuries, Economic Journal, 80, 850-872.

Krishna, K., Ozyildirim, A. and Swanson, N. (2003) Trade, investment and growth: nexus, analysis and prognosis, Journal of Development Economics, 70, 479-499.

Kwan, A., Cotsomitis, J and Kwok, B. (1999) Exports, economic growth and structural invariance: evidence from some Asian NICs, Applied Economics, 31, 493-498.

Kwan, A. and Kwok, B. (1995) Exogeneity and the exports-led growth hypothesis: the case of China, Southern Economic Journal, 5, 105-117.

Love, J. and Chandra, R. (2004) Testing export-let growth in India, Pakistan and Sri Lanka using a multivariate framework, The Manchester School, 72, 483-496.

Lucas, R. (1988) On the mechanics of economic development, Journal of Monetary Economics, 22, 3-42

Markusen, J. and Venables, J. (1998) Multinational firms and the new trade theory, Journal of International Economics, 46, 183-203.

Nair- Reichert, U. and Weinhold, D. (2001) Causality tests for cross-country panels: new look at FDI and economic growth in developing countries, Oxford Bulletin of 
Economics and Statistics, 63, 153-171.

Nidugala, G. (2000) Exports and economic growth in India: an empirical investigation', The Indian Economic Journal, 47, 68-78.

Oulton, N. (1998) Investment, capital and foreign ownership in UK manufacturing. National Institute of Economic and Social Research (NIESR) Discussion Paper, No. 141.

Reserve Bank of India (2003) India's foreign liabilities and assets. Reserve Bank of India Bulletin, June.

Romer, P. (1993) Idea gaps and object gaps in economic development, Journal of Monetary Economics, 32, 543-573.

Shan, J. and Sun, F. (1998) On the export-led growth hypothesis: the econometric evidence from China, Applied Economics, 30 1055-1065.

Solow, R. (1956) A contribution to the theory of economic growth, Quarterly Journal of Economics, 70, 65-94.

Sun, H. (1998) Foreign Direct Investment and Economic Development in China: 19791996, Ashgate, England.

Thangavelu, S. and Rajaguru, G. (2004) Is there an export or import-led productivity growth in rapidly developing Asian countries? A multivariate VAR analysis, Applied Economics, 36, 1083-1093.

Toda, H. and Phillips, C. (1993) Vector autoregression and causality, Econometrica, 61, 1367-1393.

UNCTAD (2001) World Investment Report, New York and Geneva: United Nation. UNCTAD (2003) FDI/TNC database in web-site: http://www.unctad.org 
Venables, A. (1996) Trade policy, cumulative causation, and industrial development, Journal of Development Economics, 49, 179-197.

Wang, Z. Q. and Swain, N. (1997) Determinants of inflow of foreign direct investment in Hungary and China: time-Series approach, Journal of International Development, 9, 695-726.

$\mathrm{Xu}$, B. (2000) Multinational enterprises, technology diffusion, and host country productivity growth, Journal of Development Economics, 62, 477-493.

Young, A. (1994) Lessons from the East Asian NICs: a contrarian view, European Economic Review, 38, 964-973. 
Table 1:Unit root tests: Null hypothesis: LGDP, LFDI, LEX and LIM contain a unit root

\begin{tabular}{|c|c|c|c|c|c|c|c|c|}
\hline \multirow[t]{2}{*}{ Economy } & \multicolumn{2}{|c|}{ GDP } & \multicolumn{2}{|c|}{ FDI } & \multicolumn{2}{|c|}{ EXPORTS } & \multicolumn{2}{|c|}{ IMPORTS } \\
\hline & LGDP & DLGDP & LFDI & DLFDI & LEX & DLEX & LIM & DLIM \\
\hline Hong Kong & -2.37 & $-4.80 * * *$ & -1.80 & $-5.72 * * *$ & -0.67 & $-3.28^{*}$ & -1.67 & $-5.58 * * *$ \\
\hline India & -1.73 & $-4.91 * * *$ & -2.53 & $-6.31 * * *$ & -1.71 & $-6.64 * * *$ & -2.14 & $-4.14 * * *$ \\
\hline Indonesia & -1.63 & $-5.63 * * *$ & -1.89 & $-4.95 * * *$ & -2.36 & $-4.07 * *$ & -1.90 & $-3.71 * *$ \\
\hline S. Korea & -2.19 & $-4.79 * * *$ & -2.03 & $-5.72 * * *$ & -2.18 & $-3.47^{*}$ & -2.67 & $-5.58 * * *$ \\
\hline Malaysia & -1.76 & $-4.15^{* *}$ & -1.39 & $-4.45 * * *$ & -1.85 & $-8.04 * * *$ & -1.88 & $-3.69 * *$ \\
\hline Philippines & -2.06 & $-3.39^{*}$ & -2.58 & $-7.22 * * *$ & -1.69 & $-3.27 *$ & -1.84 & $-3.62 * *$ \\
\hline Singapore & -1.79 & $-3.93 * *$ & -1.44 & $-8.55 * * *$ & -1.49 & $-3.57 * *$ & -1.71 & $-3.87 * *$ \\
\hline Thailand & -1.01 & $-4.15 * * *$ & -2.16 & $-6.42 * * *$ & -207 & $-5.30 * * *$ & -2.07 & $-4.08 * * *$ \\
\hline Taiwan & -1.79 & $-3.81 * *$ & -3.19 & $-7.31 * * *$ & -2.42 & $-4.88 * * *$ & -1.58 & $-4.17 * * *$ \\
\hline
\end{tabular}

Notes: $* * *, * *$ and $*$ denote significance at the $1 \%, 5 \%$ and $10 \%$ level, respectively.

Table 2: Results from cointegration tests

\begin{tabular}{lcccccc}
\hline \multirow{2}{*}{ Economy } & \multicolumn{2}{c}{$\begin{array}{c}\text { Maximal eigenvalue statistics } \\
\text { Under the H0: } \mathbf{r a n k}=\mathbf{r}\end{array}$} & \multicolumn{3}{c}{$\begin{array}{c}\text { Trace statistics } \\
\text { Under the H0: } \mathbf{r a n k}=\mathbf{r}\end{array}$} \\
\cline { 2 - 7 } & $\mathbf{r}=\mathbf{0}$ & $\mathbf{r} \leq \mathbf{1}$ & $\mathbf{r} \leq \mathbf{2}$ & $\mathbf{r}=\mathbf{0}$ & $\mathbf{r} \leq \mathbf{1}$ & $\mathbf{r} \leq \mathbf{2}$ \\
\hline Hong Kong (4) & $85.07^{* *}$ & $35.36^{* *}$ & 7.08 & $145.4^{* *}$ & $60.4^{* *}$ & 10.2 \\
India (4) & $48.99^{* *}$ & $25.6^{* *}$ & 9.48 & $90.27^{* *}$ & $40.28^{* *}$ & 14.69 \\
Indonesia (3) & $48.2^{* *}$ & $23.45^{* *}$ & 10.33 & $87.04^{* *}$ & $38.84^{* *}$ & 15.37 \\
S. Korea (4) & $39.21^{* *}$ & $31.98^{* *}$ & 13.05 & $95.55^{* *}$ & $56.34^{* *}$ & 10.44 \\
Malaysia (4) & $54.41^{* *}$ & $32.31^{* *}$ & 9.66 & $104.2^{* *}$ & $50.06^{* *}$ & 17.75 \\
Philippines (3) & $36.91^{* *}$ & $25.18^{* *}$ & 7.13 & $69.75^{* *}$ & $32.84^{* *}$ & 7.66 \\
Singapore (2) & $30.89^{* *}$ & $23.6^{* *}$ & 11.8 & $79.7^{* *}$ & $48.81^{* *}$ & 18.01 \\
Thailand (3) & $31.9^{* *}$ & $29.32^{* *}$ & 10.4 & $79.89^{* *}$ & $47.99^{* *}$ & 18.67 \\
Taiwan (4) & $57.09^{* *}$ & $34.9^{* *}$ & 11.5 & $105.4^{* *}$ & $48.33^{* *}$ & 15.75 \\
\hline
\end{tabular}

Notes: figures in parentheses are the number of lags used. 
Table 3: System exogeneity tests: long-run causality

\begin{tabular}{lllllllll}
\hline \multirow{2}{*}{ Economy } & \multicolumn{7}{c}{ System exogeneity tests: $\mathbf{X}^{\mathbf{2}(2)}$} \\
& \multicolumn{7}{c}{ HO: the variables (LGDP, LFDI. LEX \& LIM) weakly exogenous to system } \\
\cline { 2 - 9 } & LR test & P-value & LR test & P-value & LR test & P-value & LR test & P-value \\
\cline { 2 - 9 } Hong Kong & 7.16 & $<0.05$ & 22.41 & $<0.01$ & 19.21 & $<0.01$ & 22.98 & $<0.01$ \\
India & 4.66 & $<0.10$ & 34.51 & $<0.01$ & 18.89 & $<0.01$ & 0.67 & $<0.95$ \\
Indonesia & 62.91 & $<0.01$ & 27.59 & $<0.01$ & 40.09 & $<0.01$ & 50.18 & $<0.01$ \\
S. Korea & 5.06 & $<0.10$ & 26.05 & $<0.01$ & 17.41 & $<0.01$ & 12.10 & $<0.01$ \\
Malaysia & 15.19 & $<0.01$ & 12.79 & $<0.01$ & 5.42 & $<0.10$ & 1.31 & $<0.52$ \\
Philippines & 10.83 & $<0.01$ & 19.90 & $<0.01$ & 6.47 & $<0.05$ & 7.19 & $<0.05$ \\
Singapore & 17.75 & $<0.01$ & 8.02 & $<0.05$ & 10.10 & $<0.01$ & 8.16 & $<0.05$ \\
Thailand & 7.43 & $<0.05$ & 29.83 & $<0.01$ & 5.83 & $<0.05$ & 16.55 & $<0.01$ \\
Taiwan & 22.76 & $<0.01$ & 16.78 & $<0.01$ & 11.67 & $<0.01$ & 7.09 & $<0.05$ \\
\hline
\end{tabular}




\title{
Trade, Foreign Direct Investment and Economic Growth in Asian Economies
}

\author{
Xiaohui Liu* \\ Business School \\ Loughborough University \\ Leicestershire LE11 3TU \\ Chang Shu \\ Hong Kong Monetary Authority \\ Peter Sinclair \\ Department of Economics \\ Birmingham University
}

October 2006

Running title: Trade, FDI and Economic Growth

\begin{abstract}
Despite the increasing role of foreign direct investment (FDI) in economic development, very limited research has been carried out on the causal links between trade, FDI and economic growth in Asian economies. This study examines empirically the interplay between exports, imports, FDI and economic growth for nine Asian economies by conducting multivariate causality tests in the VECM framework. The results reveal twoway causal connections between trade, inward FDI, inward merger and acquisitions (M\&As), and growth for most of the sample economies. There is a unidirectional causal link running from outward M\&As to growth and trade. These findings suggest that export expansion, import liberalisation, FDI inflows and inward M\&As are integral elements of the growth process in Asian economies.
\end{abstract}

JEL Classification: C32, F21, O53

\footnotetext{
* Corresponding author: Business School, Loughborough University, Leicestershire, LE11 3TU; Tel No 01509-223349; Fax No: 01509-223171; Email: X.liu2@,lboro.ac.uk
} 


\title{
Trade, Foreign Direct Investment and Economic Growth in Asian Economies
}

\author{
1 Introduction
}

The relationship between trade and economic growth has received increasing attention from academics and policy markers. A large number of empirical studies have been carried out on causality between trade and growth, particularly for East Asian economies (Hsiao, 1987; Chen and Tang, 1990; Ahmad and Harnhirun, 1995; Islam, 1998; Kwan et al, 1999; Hatemi-J, 2002 and Jin, 2002; Love and Chandra, 2004; Thangavelu and Rajaguru, 2004; Awokuse, 2006). These studies have shed some light on the issue and provided some useful insights regarding the evaluation of trade and development strategies. However, most of the existing studies exclude FDI and only consider tradegrowth linkage with the exception of Yao (2006), despite the fact that FDI inflows and multinationals have become the driving forces of economic growth and technology transfer (Kokko, 1994; Oulton, 1998; Xu, 2000). Over the last two decades, East Asian economies, in particular, have received increasing amounts of inward FDI which reached a record level of US\$155.5 billion in 2005 (FDI Confidence Index, 2005). In contrast, comparatively few studies have been conducted on the relationship between trade, FDI and economic growth for Asian economies in a multivariate framework.

It is important to examine the linkage between trade, FDI and economic growth for Asian economies in order to provide evidence as to whether rapid economic growth in the region is driven by trade and FDI, or whether there is reciprocal impact between growth, trade and FDI. Such an investigation can explore the degree to which the positive 
association between trade, FDI and growth is due to the fact that trade and FDI stimulate growth, and to what extent this positive association reflects the fact that growth leads to trade and FDI. In addition, there is a lack of research on the impact of cross-border merger and acquisitions (M\&As) on growth in Asian economies although M\&As have become a more important source of foreign investment and a dominant mode of FDI entry into the region. In general, the region has experienced a rapid increase in crossborder M\&As since the late 1990s (Chen and Findlay, 2003).

Moreover, by including economies at different stages of development in the study, it is possible to address the question of whether the level of development affects the pattern of the relationship between the four important economic variables. From a policy point of view, investigating the causal links between trade, FDI and growth generates important implications for the development strategies of developing countries.

The sample used in this study consists of the first and second wave of newly industrialised economies (NIEs) in East Asia, notably Hong Kong, Singapore, South Korea, Taiwan, Indonesia, Malaysia, the Philippines and Thailand. In addition, a large developing country in the region, India, is also included. An appropriate model will be selected for individual economies in order to best capture the complicated relationship between these variables.

This research differs from previous studies in several ways. First, instead of using different measures of openness and trade policy, we examine the three basic elements of development strategy, notably exports, imports and FDI. Most of the previous causality tests assume implicitly that the coefficients on exports and imports are homogeneous (Krishna, et al, 2003) and use trade shares to measure openness. However, in this study, 
we treat exports and imports separately to allow for the possibility that their influence is asymmetric. Second, we regard FDI, including cross-border M\&As, as a key factor of economic growth, given that in addition to its direct contribution to GDP, FDI has played an increasingly important role in technology transfer and R\&D spillovers in developing countries (Blomstrom and Sjoholm, 1999; Gao, 2004). Therefore, we consider exports, imports and FDI as external links, and attempt to test the causal relationship between these factors and economic development in selected Asian economies.

The paper is structured as follows: Section 2 discusses the theoretical foundations for possible bi-directional linkage between external factors and economic growth. Section 3 introduces the methodology and data used in the study, while the following section presents and analyses empirical results. Section 5 concludes with policy implications.

2 Trade, FDI and Growth: a discussion of theoretical linkage and the empirical evidence

The theoretical foundations for empirical studies on trade, FDI and growth are derived from neoclassical and endogenous growth models. In neoclassical growth models, factor accumulation is considered as a driving force of growth. FDI, as a factor of production, increases investment as well as enhances efficiency, and provides growth momentum in the medium-term. Application of the Solow model (1956) implies that a trade-induced rise in production leads to transitional growth when the economy adjusts to a new steadystate equilibrium as specialisation and the realisation of external economies of scale through trade allow the economy to transform its given input into a greater value of final output. Ben-David and Loewy (2003) extend the traditional neoclassical exogenous 
growth model by incorporating the impact of openness on growth within a multi-country framework and the results from their model indicate that the extent of trade liberalisation can affect the endogenously determined growth rate in the steady state.

The new endogenous growth models establish the links between long-run growth and technological progress, and provide a framework in which trade and FDI can permanently increase the rate of growth in the host country through technology transfer, diffusion, and spillover effects. Romer (1993) points out that one benefit that trade brings is access to new ideas. Grossman and Helpman (1991) have constructed a theoretical model to show formally that trade in goods serves as a conduit for knowledge flows between countries. These flows in turn serve to increase the productivity of capital and labour and hence the growth rate of output per head. Borensztein et al (1998) develop a growth model in which technological progress, represented by increasing varieties of capital goods, is determined by FDI as multinationals can reduce the costs of introducing new varieties of capital goods. Thus, FDI acts as the main vehicle of technology transfer. In addition, the human capital building model as presented by Lucas (1988) may suggest that trade and FDI could enable inter-country technology transfer, particularly if it reduced the cost or raised the productivity of training.

Although trade and FDI are important for economic growth, the causal link between them is not necessarily uni-directional. The level of economic development can also influence trade and FDI. Theoretical justifications for reverse causation from growth to trade and FDI have long been discussed in development literature (Kanamori, 1968; Diaz-Alejandro, 1975; Kravis, 1970; Findlay, 1984). It is argued that output growth has a positive impact on productivity growth, which in turn acts as a stimulus to exports 
(Kaldor, 1967). Jung and Marshall (1985) suggest that internal growth mechanisms better explain export growth rather than the reverse. In new trade theory, the market structure and output expansion may trigger significant changes in exports through a process of "cumulative causation" (Venables, 1996). A more recent study by Berthelemy and Demurger (2000) has theoretically established that FDI is influenced by the growth rate of the economy in the long run, and thus provides a formal justification of the causal link between growth and FDI.

Regional integration also affects the inflow and outflow of FDI among member and non-member countries. This is because regional economic integration which results in reductions in trade barriers and investment restrictions may change location-specific advantages, and so affect FDI inflows directly. Moreover, regional economic integration may indirectly affect economic growth, which in turn should affect FDI flows. Theoretically, a regional integration agreement (RIA) would lead to an increase in inward FDI among member countries due to factor endowments, agglomeration economies and favourable regulatory environments. Inflows of FDI from non-member countries into the region are likely to increase if the average level of protection facing outsiders increases, or if the establishment of an RIA raises fears about future protection. In addition, inflows of FDI may also rise if a RIA leads to an enlarged regional market which acts as a magnet for 'outsiders' (Blomstrom and Kokko, 1998). For example, intra-regional FDI flows in Asia have increased over the years, accounting for an estimated $46 \%$ of total flows to the region in 2002. To non-member countries, Asia is an attractive destination for FDI and cross-border M\&As, amounting to 23\% of total FDI worldwide in 2004 (The World Investment Report, 2005). 
Given the possible bi-directional relationship between trade, FDI and economic growth postulated by the theories, the issue becomes empirical and can be verified through statistical tests. Attempts have been made to establish a causal link between trade, FDI and growth empirically. Previous studies in this area fall roughly into three groups. The first group focuses on the impact of trade or openness on economic growth. Early works, including Balassa (1978, 1984), Feder, (1983), and Kavoussi (1984), only consider causation running from exports to economic growth. Studies of this kind assume implicitly that exports are exogenous without taking reverse causation into account.

Studies in the second group examine the impact of economic growth on FDI. The extent to which FDI can be explained by economic growth is the focus of attention, particularly the determinants of FDI in developing countries (Wang, and Swain, 1997; Dees, 1998). These studies, which assume one-way causality from growth to FDI, appear to indicate that the growth potential in developing economies is the main determinant of inward FDI. These studies have, however, also neglected the possible simultaneity between FDI and growth.

The third group of studies attempts to investigate bi-directional causal links between trade and growth or FDI and growth, by conducting causality tests. Mixed results have been obtained. Jung and Marshall (1985) have found that only four out of 37 developing countries support the export-led growth hypothesis. Studies by Chow (1987), Hsiao (1987), and Chen and Tang (1990) are only able to provide weak support for the export-led growth hypothesis even for highly export-oriented economies such as Hong Kong, Singapore and Taiwan. Those results are consistent with Young's findings (1994) which indicate that outward orientation may or may not be associated with rapid 
productivity growth, and the fast expansion of East Asian NIEs should not be viewed as evidence of the potential dynamic gains from outward-oriented policies. On the other hand, Ahmad and Harnhirun (1995), Biswal and Dhawan (1998), Islam (1998), Shan and Sun (1998) have found bi-directional causality for most of the East Asian NIEs and China. However, most of the cited studies have treated exports as the principal channel through which openness can affect economic growth. None of them include FDI inflows in their empirical analysis despite the fact that East Asian economies have received increasing amounts of inward FDI. Therefore, using trade as a proxy for openness may be inadequate without taking the impact of FDI into account (Proudman and Redding, 1998; Goldberg and Klein, 1999). Furthermore, the existence of a FDI-growth nexus is not considered by excluding FDI variable from causality tests.

The most recent study by Nair-Reichert and Weinhold (2001) acknowledges the problems mentioned above by considering the complex and heterogeneous relationship between FDI and growth. They have found a causal relationship from FDI to growth, and some evidence that the efficacy of FDI is higher in more open economies. However, in their study, imports are not used as the measure of openness and this may underestimate the impact of trade induced by imports (Keller and Yeaple, 2003). Extending previous work in this area, the present study attempts to estimate the complex interaction between trade, FDI and growth for selected Asian economies in a multivariate framework.

3 The methodology and data 
We are interested in the interplay of four variables, GDP, FDI, Exports and Imports; to set the scene, therefore, consider a VAR involving four variables, W, X, Y, and Z. In a stationary setting, a Granger causality test in such a structure would be carried out (following Ghartey, 1993) via the following regressions:

$$
\begin{aligned}
& W_{t}=\delta_{0}+\sum_{i=1}^{m} \delta_{1 i} W_{t-i}+\sum_{j=1}^{m} \delta_{2 j} Z_{t-j}+\sum_{k=1}^{m} \delta_{3 k} Y_{t-k}+\sum_{l=1}^{m} \delta_{4 l} X_{t-l}+u_{1 t} \\
& X_{t}=\varphi_{0}+\sum_{i=1}^{n} \varphi_{1 i} X_{t-i}+\sum_{j=1}^{n} \varphi_{2 j} Y_{t-j}+\sum_{k=1}^{n} \varphi_{3 k} Z_{t-k}+\sum_{l=1}^{n} \varphi_{4 l} W_{t-l}+u_{2 t} \\
& Y_{t}=\theta_{0}+\sum_{i=1}^{p} \theta_{1 i} Y_{t-i}+\sum_{j=1}^{p} \theta_{2 j} X_{t-j}+\sum_{k=1}^{p} \theta_{3 k} Z_{t-k}+\sum_{l=1}^{p} \theta_{4 l} w_{t-l}+u_{3 t} \\
& Z_{t}=\gamma_{0}+\sum_{i=1}^{q} \gamma_{1 i} Z_{t-i}+\sum_{j=1}^{q} \gamma_{2 j} Y_{t-j}+\sum_{k=1}^{q} \gamma_{3 k} X_{t-k}+\sum_{l=1}^{q} \gamma_{4 l} W_{t-l}+u_{4 t}
\end{aligned}
$$

$t=1,2, \ldots, N$

where the lag lengths, $(m, n, p, q)$ are determined so that $u_{1 t}, u_{2 t}, u_{3 t}$ and $u_{4 t}$ are serially uncorrelated. The null hypothesis ' $Y$ does not Granger cause $X$, given $W$ and $Z$ ' is tested via a standard F- test, being rejected if the $\varphi_{2 j}$ in equation (2) are jointly significant. Similarly, if the $\theta_{2 j}$ in equation (3) are jointly significantly different from zero, the null hypothesis that $X$ does not Granger cause $Y$, given $W$ and $Z$, is rejected and so on. However, if the series are non-stationary, it becomes important to determine whether or not they are cointegrated, as this affects the sampling distributions of the causality tests. 
Toda and Phillips (1993) show that levels autoregressions are an unreliable basis for inference about causality in the nonstationary case, since the sampling distributions of the test statistics depend on the ranks of certain sub-matrices in the cointegrating space. They thus favour the use of the VECM framework of Johansen (1988) in which the necessary information about the cointegrating space is available, and where causality test statistics will usually have asymptotic Chi-square distributions. We adopt this approach.

When the series in the VAR are cointegrated, and have two cointegrating vectors, ignoring the higher-order dynamics, equations (1)-(4) above can be rewritten in the VECM form:

$\left[\begin{array}{c}\Delta W \\ \Delta X \\ \Delta Y \\ \Delta Z\end{array}\right]_{t}=\left[\begin{array}{ll}\alpha_{11} & \alpha_{12} \\ \alpha_{21} & \alpha_{22} \\ \alpha_{31} & \alpha_{32} \\ \alpha_{41} & \alpha_{42}\end{array}\right]\left[\begin{array}{llll}\beta_{11} & \beta_{12} & \beta_{13} & \beta_{14} \\ \beta_{21} & \beta_{22} & \beta_{23} & \beta_{24}\end{array}\right]\left[\begin{array}{c}W \\ X \\ Y \\ Z\end{array}\right]_{t-1}+\left[\begin{array}{l}\varepsilon_{1} \\ \varepsilon_{2} \\ \varepsilon_{3} \\ \varepsilon_{4}\end{array}\right]_{t}$

where the parameters of interest are in the long-run (i.e. cointegrating) vectors, $\beta_{i j}$, and the adjustment coefficients (loading factors), $\alpha_{i j}$. Hall and Milne (1994, pp 600-601) introduce the notion of the absence of weak causality to denote the situation in which the long-run level of one or more variables is unaffected by the levels of others. In equation (5), this is testable via zero restrictions on $\alpha_{i j}$. Following Hall and Milne, if weak noncausality is rejected, then Granger non-causality, which in addition involves the remaining higher-order short-run dynamics, is also rejected. Thus bi-directional causality can be explored by estimating the full VECM proposed in equation (5), and testing restrictions on the long-run adjustment coefficients. 


\section{Data}

Annual data for the value of exports and imports in goods for ten economies are taken from UNCTAD (2003). The export and import price indices are used to deflate the value of exports and imports for most economies, but GDP deflators $(1995=100)$ are used instead for Singapore and Thailand, where those indices are unavailable. There are several sources for obtaining inward FDI including the UNCTAD (2003), Reserve Bank of India (2003) and Bank Indonesia (2003). Annual GDP series are taken from the International Financial Statistics (2003). Both GDP series and inward FDI are deflated using GDP deflators. The sample period spans from 1970 to 2002 for the nine economies.

The data on cross-border M\&As are obtained from the UNCTAD FDI dataset. The variables of inward and outward M\&As are deflated using GDP deflators. The time span for the M\&A data is from 1990 to 2004 and is relatively short for a time-series analysis; hence, we conduct a panel causality test using the variables of inward and outward M\&As to replace the FDI variable.

The reason for incorporating M\&As into the study is that M\&As represent an increasing trend in Asian economies, amounting to \$25 billion in 2005 (The World Investment Report, 2005). It has been observed that the governments of the sample countries, such as South Korea, Indonesia, the Philippines and Thailand have adopted favourable policies and measures to encourage cross-border M\&As. In particular, South Korea relaxed all the restrictions on acquisitions by foreign investors in 1998 as one of the structural reforms in the wake of the economic crisis. As a result, the share of M\&A investment in total FDI inflows into the country rose to 53\% in 1998 (The World Investment Report, 2005). 
In addition, many Asian countries have introduced favourable policy measures in order to enhance their economies' attractiveness for FDI. For example, China has relaxed ownership restrictions and geographical limitations previously imposed on FDI in distribution services. The Indian government has also adjusted foreign-equity ceilings in various industries in order to attract more foreign investors. Similar measures have been taken by the other sample countries. These incentives towards FDI and M\&As play an important role in inducing FDI inflows. As all the sample economies have adopted similarly favourable incentives and policies towards FDI and M\&As during the sample period, we mainly focus on the inter-relationship between FDI, M\&As, GDP, Exports and Imports by taking favourable policies towards FDI as given.

\section{Empirical results}

\section{Unit root tests}

The series are transformed into logarithms so that the first differences correspond to growth rates. Table 1 presents the results from ADF unit root tests with lag length chosen by downward search (t-test on the longest lag). The null hypothesis of a unit root in the logarithm is not rejected for any of the four variables in levels. However, each of the logged series is stationary in first differences. Therefore all the variables are integrated of order one. We also conduct a panel unit-root test for the variables of M\&As, GDP, exports and imports. The results summarised in Table 2 suggest that the variables contain a unit root in levels and are stationary in first differences.

Insert Tables $1 \& 2$, here 


\section{Cointegration tests}

When testing cointegration relationships we first need to decide whether deterministic components such as constant, time trend and dummy variables should be included in the model. Using the general-to-specific approach, a specific model for each economy is chosen. The selection criterion for lag length is the combination of Akaike Information Criterion and diagnostic tests. The selected lag length should enable residuals to pass various diagnostic tests, including serial correlation, normality, function form, ARCH and heteroskedasticity. Second, the test for cointegration rank described by Johansen and Juselius (1990) is applied, and the results are reported in Table 2. Both trace statistics and maximal eigenvalue statistics show that the VAR for each economy has two cointegrating vectors; both are significant at the $5 \%$ and $1 \%$ levels. The existence of cointegration between the variables suggests that there are long-run relationships between the four variables, implying that there is a tendency for the four variables to move together.

We also perform a panel integration test. The results (Table 4) show that there is one panel cointegration vector between inward M\&As, outward M\&As, GDP, Exports and Imports. The existence of the long-run relationship between the five variables in the panel cointegration test suggests that it is appropriate to conduct a long-run panel causality test.

Insert Tables 3 and 4, here

\section{Testing for weak exogeneity and causality}

The results from cointegration tests indicate that the causality tests should be conducted 
via Equation (5). As stated in Section 3, the main interest of the study is to test long-run relationships, hence we investigate the long-run causality between the four variables which is equivalent to testing long-run loading factors in equation (5), such as $a_{i j}=0$. The results reported in Table 3 reveal that exports, imports and FDI affect GDP in most of the sample economies at the $1 \%$ or $5 \%$ significance levels. The results confirm that external links represented by exports, imports and FDI have generated beneficial effects on economic growth in most of the sample economies, indicating that the external links may act as the principal channel through which technology spillover and learning-bydoing take place as suggested by endogenous growth theories. The evidence that economies with different levels of development exhibit the same pattern in trade-growth and FDI-growth nexus suggests that trade and FDI are important factors in enhancing economic growth, regardless of the initial level of development.

\section{Insert Table 5, here}

It should be noted that the null hypothesis, that GDP is exogenous, is rejected only at the $10 \%$ significance level in the cases of India and South Korea. This may reflect the fact that India has been a relatively closed economy with an inward-looking policy which was relaxed relatively late, with final removal of its last features coming only in the mid-1990s. Therefore, it is highly likely that the impact of trade and FDI on GDP is relatively small at the aggregate level. However, it is very surprising that Korean GDP is only weakly affected by external factors, given that the remarkably rapid economic growth over most of the last few decades has been accompanied by persistent export expansion. One reason might be that South Korea adopted an export promotion policy under import protection. It is also well known that the Korean government restricted 
inward FDI until the Asian financial crisis. All these factors may create distortions, and limit the impact of trade and FDI on GDP.

The null hypothesis that FDI is exogenous is universally rejected across the sample economies, implying that inward FDI is attracted by the growth prospects and the level of external trade in the region. The results are consistent with previous studies which have found that rapid GDP growth and intensive external trade act as the main determinants of inward FDI (Broadman and Sun, 1997; Sun, 1998).

The evidence rejects the null hypothesis that exports are exogenous for all the sample economies. The only weak result obtained is for Malaysia where the null hypothesis is rejected at the $10 \%$ significance level, showing a weak causal link between exports and the other three variables. The results indicate that exports and the other three variables mutually affect each other. In terms of imports, the results in eight out of ten sample economies reject the hypothesis that imports are exogenous, suggesting that imports are linked to GDP, exports and FDI. However, the null hypothesis is not rejected in the cases of India and Malaysia, confirming that only a one-way causal link running from imports to GDP exists. Import-led growth has been achieved in these two countries. In particular, Indian imports grew faster than exports between 1970 and 1990. Import liberalisation helped reduce import shortages, and hence facilitated economic growth (Nidugala, 2000). The result shows that imports of capital goods may have been especially important. They are found to be a more important influence on growth than openness by Sala-I-Martin et al (2004).

Based on the four weak exogeneity tests (weak causality - after Hall and Milne) which massively reject the null hypothesis for each of the four variables for 8 out of 9 
sample economies, we conclude that each is caused by the other three. This implies in turn that we have bi-directional Granger causality for the majority of the sample economies. Bi-directional causalities between the four variables do not support a tradeled or a FDI-led growth hypothesis (Kwan and Kwok, 1995; Nair-Reichert and Weinhold, 2001). The findings suggest that export expansion, import liberalisation and FDI inflows are integral elements in the economic growth process and that these external links go hand in hand with growth in Asian economies.

Insert Table 6, here

The results from panel causality tests show that there are two-way relationships between GDP, Inward M\&As, Exports and Imports as found in the time series analysis, suggesting that these variables all affect each other. However, the result is unable to reject the null hypothesis that the variable of outward M\&As is exogenous, indicating that outward M\&As from emerging Asian economies may be driven by firm level strategies and changes in the global business environment rather than countries' economic growth and trade perspectives.

Taken together, we have found evidence that inward FDI, either in greenfield investment or cross-border M\&As, is significantly affected by countries' growth and external trade. In turn, FDI and inward M\&As also boost economic growth as well as trade. Hence, we have obtained evidence that inward FDI and inward M\&As have a similar impact on host countries. However, there is a uni-directional relationship between growth and outward M\&As, suggesting that outward M\&As in the sample economies have generated a detectable impact on growth - and also on trade - at the aggregate level. 
5 Conclusions

This study examines empirically the causal links between FDI, trade and growth for nine Asian economies by conducting multivariate causality tests in the VECM framework and panel data analysis by incorporating inward M\&As and outward M\&As in the estimation. The results reveal two-way causal connections between trade, inward FDI, inward M\&As and growth for most of the sample economies, indicating that external links and growth mutually affect each other. We have found that there is a unidirectional causal link running from outward M\&As to growth and trade, indicating that outward M\&A activities in the sample economies may be driven by firms' global strategies and changes in the global business environment. The findings suggest that export expansion, import liberalisation, FDI inflows and inward M\&As are integral elements in the growth process in the sample Asian economies. The existence of bi-directional causal links suggests that development strategies should be designed to promote inward FDI, inward M\&As, trade and growth simultaneously.

This study investigating the causal links between growth, FDI and trade has yielded a number of interesting insights into the complex relationship between these variables. It will be worthwhile in further research to examine the interrelationship between R\&D investment, trade, FDI and growth. 


\section{References}

Ahmad, J. and Harnhirun, S. (1995) Unit roots and cointegration in estimating causality between exports and economic growth: empirical evidence from the ASEAN countries, Economics Letters, 49, 329-334.

Awokuse, T. (2006) Export-led growth and the Japanese economy: evidence from VAR and directed acyclic graphs, Applied Economics, 38, 593-602.

Balassa, B. (1978) Exports and economic growth: further evidence, Journal of Development Economics, 5, 181-189.

(1985) Exports and policy choices and economic growth in developing countries after the 1973 oil crisis, Journal of Development Economics, 18, 23-35.

Bank Indonesia (2003) Annual report for direct investment and services and investment income in 2002.

Berthelemy, J. and Demurger, S. (2000) Foreign direct investment and economic growth: theory and application to China, Review of Development Economics, 4, 140-155.

Biswal, B. and Dhawan, U. (1998) Export-led growth hypothesis: cointegration and causality analysis for Taiwan, Applied Economics Letters, 5, 699-701.

Ben-David, D. and Loewy, M. (2003) Trade and the Neoclassical growth model, Journal of Economic Integration, 18, 1-16.

Blomstrom, $M$ and Kokko, A. (1997) Regional Integration and Foreign Direct Investment, NBER Working Papers, No 6019.

Blomstrom, M. and Sjoholm, F. (1999) Technology transfer and spillovers: Does local participation with multinationals matter?, European Economic Review, 43, 915-923.

Borensztein, E., Gregorio, J. and Lee, J. (1998) How does foreign direct investment affect 
economic growth', Journal of International Economics, 45, 115-135.

Broadman, G and Sun, X. (1997) The distribution of foreign direct investment in China, World Economy, 20, 339-361.

Chen, C. and Findlay, C. 2003 A Review of Cross-border Mergers and Acquisitions in APEC, Asian-Pacific Economic Literature, 17, 14-68.

Chen, S., and Tang, D. (1990) Exports performance and productivity growth: the case of Taiwan, Economic Development and Cultural Change, 38, 577-585.

Chow, P. (1978) Causality between exports and industrial development: empirical evidence from the NICs, Journal of Development Economics, 26, 55-63.

Dees, S. (1998) Foreign direct investment in China: determinants and effects, Economics of Planning, 31, 175-194.

Diaz-Alejandro, C. (1975) Trade policy and economic development in P Kenen (ed.) International Trade and Finance: Frontiers for Research, New York, Cambridge University Press.

Feder, G. (1983) On exports and economic growth', Journal of Development Economics, $12,59-73$.

FDI Confidence Index (2005) Global Business Policy Council, 8, 26-28.

Findlay, R. (1984) Growth and development in trade model in R. Jones and Kenen (eds), Handbook of International Economics (I), Amsterdam, North-Holland.

Gao, T. (2004) Regional industrial growth: evidence from Chinese industries', Regional Science and Urban Economics, 34, 101-124

Ghartey, E. (1993) Causal relationship between exports and economic growth: some empirical evidence in Taiwan, Japan and the US, Applied Economics, 25, 1145-1152. 
Goldberg, S., and Klein, W. (1999) International trade and factor mobility: an empirical investigation, NBER Working Paper No. 1796.

Grossman, G. and Helpman, E. (1991) Innovation and growth in the global economy, MIT Press, Cambridge, MA.

Hall, S. and Milne, A. (1994) The relevance of p-star analysis to UK monetary policy, Economic Journal, 104, 597-604.

Hatemi-J, A. (2002) Export performance and economic growth nexus in Japan: a bootstrap approach, Japan and World Economy, 14, 25-33.

Hsiao, M. (1987) Tests of causality and exogeneity between exports and economic growth: the case of Asian NICs, Journal of Economic Development, 12, 143-159.

International Financial Statistics Yearbook (2003). Annual GDP series, IMF.

Islam, M. (1998) Export expansion and economic growth: testing for cointegration and causality, Applied Economics, 30, 415-425.

Jin, J. (2002) Exports and growth: is the export-led growth hypothesis valid for provincial economies? Applied Economics, 34, 63-76.

Johansen, S. (1988) Statistical analysis of cointegration vectors, Journal of Economic Dynamics and Control, 12, 213-254.

Johansen. S. and Juselius, K. (1990) Maximum likelihood estimation and inference on cointegration-with applications to the demand for money, Oxford Bulletin of Economics and Statistics, 52, 169-210.

Jung, W. and Marshall, P. (1985) Exports, growth and causality in developing countries, Journal of Development Economics, 18, 1-12. 
Kaldor, N. (1967) Strategic Factors in Economic Development, New York State School of Industrial and Labour Relations, Cornell University, Ithaca, NY.

Kanamori, M. (1968) Economic growth and exports in R. Klein and K. Ohkawa (eds), Economic Growth, Richard D. Irwn.

Kavoussi, R. (1984) Export expansion and economic growth: further empirical evidence', Journal of Development Economics, 14, 241-250.

Keller, W. and Yeaple, S. (2003) Multinational enterprises, international trade, and productivity growth: firm level evidence from the United States', NBER Working Paper, No. 9504.

Kokoo, A. (1994) Technology market characteristics and spillovers', Journal of Development Economics, 43, 279-293.

Kravis, I. (1970) Trade as a handmaiden of growth: similarities between the $19^{\text {th }}$ and $20^{\text {th }}$ Centuries, Economic Journal, 80, 850-872.

Krishna, K., Ozyildirim, A. and Swanson, N. (2003) Trade, investment and growth: nexus, analysis and prognosis, Journal of Development Economics, 70, 479-499.

Kwan, A., Cotsomitis, J and Kwok, B. (1999) Exports, economic growth and structural invariance: evidence from some Asian NICs, Applied Economics, 31, 493-498.

Kwan, A. and Kwok, B. (1995) Exogeneity and the exports-led growth hypothesis: the case of China, Southern Economic Journal, 5, 105-117.

Love, J. and Chandra, R. (2004) Testing export-let growth in India, Pakistan and Sri Lanka using a multivariate framework, The Manchester School, 72, 483-496.

Lucas, R. (1988) On the mechanics of economic development, Journal of Monetary Economics, 22, 3-42 
Markusen, J. and Venables, J. (1998) Multinational firms and the new trade theory, Journal of International Economics, 46, 183-203.

Nair- Reichert, U. and Weinhold, D. (2001) Causality tests for cross-country panels: new look at FDI and economic growth in developing countries, Oxford Bulletin of Economics and Statistics, 63, 153-171.

Nidugala, G. (2000) Exports and economic growth in India: an empirical investigation', The Indian Economic Journal, 47, 68-78.

Oulton, N. (1998) Investment, capital and foreign ownership in UK manufacturing. National Institute of Economic and Social Research (NIESR) Discussion Paper, No. 141. Proudman, J. and Redding, S. (1998) Openness and Growth, London: Bank of England. Reserve Bank of India (2003) India's foreign liabilities and assets. Reserve Bank of India Bulletin, June.

Romer, P. (1993) Idea gaps and object gaps in economic development, Journal of Monetary Economics, 32, 543-573.

Sala-I-Martin, X., Doppelhofer, G and Miller, R. (2004) Determinants of Long-Term Growth: A Bayesian Averaging of Classical Estimates (BACE) Approach, American Economic Review, 94, 813-835

Shan, J. and Sun, F. (1998) On the export-led growth hypothesis: the econometric evidence from China, Applied Economics, 30 1055-1065.

Solow, R. (1956) A contribution to the theory of economic growth, Quarterly Journal of Economics, 70, 65-94.

Sun, H. (1998) Foreign Direct Investment and Economic Development in China: 19791996, Ashgate, England. 
Thangavelu, S. and Rajaguru, G. (2004) Is there an export or import-led productivity growth in rapidly developing Asian countries? A multivariate VAR analysis, Applied Economics, 36, 1083-1093.

Toda, H. and Phillips, C. (1993) Vector autoregression and causality, Econometrica, 61, $1367-1393$.

UNCTAD (2001) World Investment Report, New York and Geneva: United Nations.

UNCTAD (2003) FDI/TNC database in web-site: http://www.unctad.org

UNCTAD (2005) World Investment Report, New York and Geneva: United Nations.

Venables, A. (1996) Trade policy, cumulative causation, and industrial development, Journal of Development Economics, 49, 179-197.

Wang, Z. Q. and Swain, N. (1997) Determinants of inflow of foreign direct investment in Hungary and China: time-Series approach, Journal of International Development, 9, 695726.

$\mathrm{Xu}$, B. (2000) Multinational enterprises, technology diffusion, and host country productivity growth, Journal of Development Economics, 62, 477-493.

Yao, S. (2006) On economic growth, FDI and exports in China, Applied Economics, 38, $339-352$.

Young, A. (1994) Lessons from the East Asian NICs: a contrarian view, European Economic Review, 38, 964-973. 
Table 1: Results from Unit Root Tests

Null hypothesis: LGDP, LFDI, LEX and LIM contain a unit root.

\begin{tabular}{|c|c|c|c|c|c|c|c|c|}
\hline \multirow[t]{2}{*}{ Economy } & \multicolumn{2}{|c|}{ GDP } & \multicolumn{2}{|c|}{ FDI } & \multicolumn{2}{|c|}{ EXPORTS } & \multicolumn{2}{|c|}{ IMPORTS } \\
\hline & LGDP & DLGDP & LFDI & DLFDI & LEX & DLEX & LIM & DLIM \\
\hline Hong Kong & -2.37 & $-4.80 * * *$ & -1.80 & $-5.72 * * *$ & -0.67 & $-3.28 *$ & -1.67 & $-5.58 * * *$ \\
\hline India & -1.73 & $-4.91 * * *$ & -2.53 & $-6.31 * * *$ & -1.71 & $-6.64 * * *$ & -2.14 & $-4.14 * * *$ \\
\hline Indonesia & -1.63 & $-5.63 * * *$ & -1.89 & $-4.95 * * *$ & -2.36 & $-4.07 * *$ & -1.90 & $-3.71 * *$ \\
\hline S. Korea & -2.19 & $-4.79 * * *$ & -2.03 & $-5.72 * * *$ & -2.18 & $-3.47 *$ & -2.67 & $-5.58 * * *$ \\
\hline Malaysia & -1.76 & $-4.15 * *$ & -1.39 & $-4.45 * * *$ & -1.85 & $-8.04 * * *$ & -1.88 & $-3.69 * *$ \\
\hline Philippines & -2.06 & $-3.39 *$ & -2.58 & $-7.22 * * *$ & -1.69 & $-3.27 *$ & -1.84 & $-3.62 * *$ \\
\hline Singapore & -1.79 & $-3.93 * *$ & -1.44 & $-8.55 * * *$ & -1.49 & $-3.57 * *$ & -1.71 & $-3.87 * *$ \\
\hline Thailand & -1.01 & $-4.15 * * *$ & -2.16 & $-6.42 * * *$ & -207 & $-5.30 * * *$ & -2.07 & $-4.08 * * *$ \\
\hline Taiwan & -1.79 & $-3.81 * *$ & -3.19 & $-7.31 * * *$ & -2.42 & $-4.88 * * *$ & -1.58 & $-4.17 * * *$ \\
\hline
\end{tabular}

\section{Table 2: Results from Panel Unit Root Tests}

Null hypothesis: LGDP, LEX, LIM, LIMA and LOMA contain a unit root.

\begin{tabular}{ccc}
\hline Variables & $\begin{array}{c}\text { Levin and Lin Test } \\
\text { (incl. trend) } \\
\text { Level }\end{array}$ & $\begin{array}{c}\text { Levin, and Lin Test } \\
\text { (intercept only) } \\
\text { Difference }\end{array}$ \\
\hline LGDP & -1.13 & $-3.52^{* * *}$ \\
LEX & 0.22 & $-4.58^{* * *}$ \\
LIM & -0.08 & $-4.78^{* * *}$ \\
LIMA & 1.69 & $-7.71^{* * *}$ \\
LOMA & 0.94 & $-5.43^{* * *}$ \\
\hline
\end{tabular}

Notes: LIMA and LOMA represent the log value of inward M\&As and outward M\&As. 
Table 3: Results from Cointegration Tests

\begin{tabular}{|c|c|c|c|c|c|c|}
\hline \multirow[t]{2}{*}{ Economy } & \multicolumn{3}{|c|}{$\begin{array}{l}\text { Maximal eigenvalue statistics } \\
\text { Under the H0: rank }=r\end{array}$} & \multicolumn{3}{|c|}{$\begin{array}{c}\text { Trace statistics } \\
\text { Under the H0: } \text { rank }=r\end{array}$} \\
\hline & $\mathbf{r}=\mathbf{0}$ & $r \leq 1$ & $r \leq 2$ & $\mathbf{r}=\mathbf{0}$ & $r \leq 1$ & $r \leq 2$ \\
\hline Hong Kong (4) & $85.07 * *$ & $35.36^{* *}$ & 7.08 & $145.4^{* *}$ & $60.4 * *$ & 10.2 \\
\hline India (4) & $48.99 * *$ & $25.6 * *$ & 9.48 & $90.27 * *$ & $40.28^{* *}$ & 14.69 \\
\hline Indonesia (3) & $48.2 * *$ & $23.45^{* *}$ & 10.33 & $87.04^{* *}$ & $38.84^{* *}$ & 15.37 \\
\hline $\begin{array}{l}\text { S. Korea (4) } \\
\text { Malaysia (4) }\end{array}$ & $\begin{array}{l}39.21^{* *} \\
54.41^{* *}\end{array}$ & $\begin{array}{l}31.98^{* *} \\
32.31 * *\end{array}$ & $\begin{array}{c}13.05 \\
9.66\end{array}$ & $\begin{array}{l}95.55^{* *} \\
104.2^{* *}\end{array}$ & $\begin{array}{l}56.34^{* *} \\
50.06^{* *}\end{array}$ & $\begin{array}{l}10.44 \\
17.75\end{array}$ \\
\hline Philippines (3) & $36.91 * *$ & $25.18^{* *}$ & 7.13 & $69.75^{* *}$ & $32.84^{* *}$ & 7.66 \\
\hline Singapore (2) & $30.89^{* *}$ & $23.6 * *$ & 11.8 & $79.7 * *$ & $48.81^{* *}$ & 18.01 \\
\hline Thailand (3) & $31.9 * *$ & $29.32 * *$ & 10.4 & $79.89^{* *}$ & $47.99 * *$ & 18.67 \\
\hline Taiwan (4) & $57.09^{* *}$ & $34.9 * *$ & 11.5 & $105.4^{* *}$ & $48.33^{* *}$ & 15.75 \\
\hline
\end{tabular}

Notes: figures in parentheses are the number of lags used.

Table 4: Results from Panel Cointegration Tests

\begin{tabular}{rlllll}
\hline Null & Alternative & \multicolumn{1}{c}{$\lambda_{\text {max }}$} & $95 \%$ C.V & Trace & $95 \%$ C.V. \\
\hline Rank $=0$ & $\mathrm{r} \geq 1$ & $70.28^{* *}$ & 33.88 & $91.74^{* *}$ & 69.82 \\
Rank $\leq 1$ & $\mathrm{r} \geq 2$ & 11.63 & 27.58 & 21.47 & 47.86 \\
Rank $\leq 2$ & $\mathrm{r} \geq 3$ & 8.01 & 21.13 & 9.84 & 29.79 \\
Rank $\leq 3$ & $\mathrm{r} \geq 4$ & 1.38 & 14.27 & 1.84 & 15.50 \\
Rank $\leq 4$ & $\mathrm{r}=5$ & 0.45 & 3.84 & 0.45 & 3.84 \\
\hline
\end{tabular}

Table 5: System Exogeneity tests: long-run causality

\begin{tabular}{lllllllll}
\hline \multirow{2}{*}{ Economy } & \multicolumn{7}{c}{ H0: the variables (LGDP, LFDI. LEX \& LIM) weakly exogenous to system } \\
\cline { 2 - 9 } & \multicolumn{7}{c}{ LGDP } & \multicolumn{3}{c}{ LFDI } & \multicolumn{3}{c}{ LEX } & \multicolumn{2}{c}{ LIM } \\
\cline { 2 - 9 } & LR test & P-value & LR test & P-value & LR test & P-value & LR test & P-value \\
\cline { 2 - 9 } Hong Kong & 7.16 & $<0.05$ & 22.41 & $<0.01$ & 19.21 & $<0.01$ & 22.98 & $<0.01$ \\
India & 4.66 & $<0.10$ & 34.51 & $<0.01$ & 18.89 & $<0.01$ & 0.67 & $<0.95$ \\
Indonesia & 62.91 & $<0.01$ & 27.59 & $<0.01$ & 40.09 & $<0.01$ & 50.18 & $<0.01$ \\
S. Korea & 5.06 & $<0.10$ & 26.05 & $<0.01$ & 17.41 & $<0.01$ & 12.10 & $<0.01$ \\
Malaysia & 15.19 & $<0.01$ & 12.79 & $<0.01$ & 5.42 & $<0.10$ & 1.31 & $<0.52$ \\
Philippines & 10.83 & $<0.01$ & 19.90 & $<0.01$ & 6.47 & $<0.05$ & 7.19 & $<0.05$ \\
Singapore & 17.75 & $<0.01$ & 8.02 & $<0.05$ & 10.10 & $<0.01$ & 8.16 & $<0.05$ \\
Thailand & 7.43 & $<0.05$ & 29.83 & $<0.01$ & 5.83 & $<0.05$ & 16.55 & $<0.01$ \\
Taiwan & 22.76 & $<0.01$ & 16.78 & $<0.01$ & 11.67 & $<0.01$ & 7.09 & $<0.05$ \\
\hline
\end{tabular}


Table 6: Results from Weak Exogeneity / Panel Causality Tests Sample period: $1990-2004$

\begin{tabular}{llr}
\hline System exogeneity tests: $X^{2}(2)$ & LR test & P-value \\
\hline LGDP weakly exogenous to system & 5.949 & $<0.05$ \\
LEX weakly exogenous to system & 14.613 & $<0.01$ \\
LIM weakly exogenous to system & 6.269 & $<0.01$ \\
LIMA weakly exogenous to system & 20.248 & $<0.01$ \\
LOMA weakly exogenous to system & 0.156 & $<0.70$ \\
\hline
\end{tabular}

